Article

\title{
The Contribution of Technological and Non-Technological Innovation to Environmental Performance. An Analysis with a Complementary Approach
}

\author{
Jennifer González-Blanco ${ }^{1}$, Jose Luis Coca-Pérez ${ }^{2}$ and Manuel Guisado-González ${ }^{2, *}$ \\ 1 Faculty of Economics and Business, University of Vigo, Campus Universitario, s/n, 36310 Vigo, Spain; \\ jengonzalez@uvigo.es \\ 2 Department of Financial Economics and Accounting, University of Extremadura, Av. de la Universidad, s/n, \\ 10071 Cáceres, Spain; jlcoca@unex.es \\ * Correspondence: manuelguisado@unex.es
}

Received: 3 October 2018; Accepted: 30 October 2018; Published: 2 November 2018

\begin{abstract}
In this study, we pursue two objectives. First, we analyse the influence of product, process, and non-technological innovation on environmental performance. Second, we explore the existence of complementarities or substitutabilities between the different combinations of these three types of innovations to learn which combinations improve or worsen environmental performance. The analyses were performed using data from the 2013 Technological Innovation Panel (PITEC) for Spanish manufacturing companies. We use the two-stage least-squares method as an instrumental variable estimator, which allows us to control the endogeneity and obtain consistent estimators. Our findings indicate that product innovation and process innovation have a negative influence on environmental performance. Likewise, we have also found that the simultaneous implementation of product innovation and process innovation is unconditionally substitutive and that the joint implementation of process innovation and non-technological innovation is conditionally substitutive. This result reinforces the position of those researchers who have pointed out that the association between a greater technology orientation and a better firm environmental performance is probably too simplistic. Finally, it should be emphasized that only non-technological innovation contributes to achieving better environmental performance and that the joint implementation of product innovation and non-technology innovation is conditionally complementary.
\end{abstract}

Keywords: product innovation; process innovation; non-tecnological innovation; environmental performance; complementarity approach

\section{Introduction}

Environmental innovation is similar to conventional innovation [1]. What differentiates environmental innovation and conventional innovation is the objectives that they pursue. In this sense, environmental innovation is usually defined as the innovation that aims at sustainable development through the reduction of environmental risks, pollution, and other negative impacts that are derived from the corresponding use of resources [2]. However, the achievement of the objectives that environmental innovation pursues is influenced by the different types of innovation that exist and are implemented [3]. These types of innovations can be classified as technological, in case of product or process innovations, or as non-technological, in the case of marketing or organizational innovations [4].

In relation to environmental innovation, this paper pursues two central objectives. First, we analyse the extent to which the different types of classical innovation (product, process, 
organizational, and marketing) contribute to achieving the objectives that environmental innovation pursues (hereinafter, environmental performance). As far as our knowledge extends, only one study tries to analyse the influence of the four basic types of innovation (product, process, organizational, and marketing) on environmental performance [5]. Our paper contributes to extending and completing this investigation by providing more empirical evidence about the impact of the four basic types of innovation on the objectives that environmental innovation pursues.

Second, we analyse the existence of positive and negative synergies (complementarities and substitutabilities) between the different combinations of these four types of innovation. In conventional innovation, studies of this kind exist, although they are scarce (e.g., References [6,7]) due to the difficulty involved in conducting them [8]. In the field of environmental innovation, we are not aware of the existence of any previous research. This paper tries to fill the gap by providing empirical evidence in the field of environmental innovation.

To check the existence of complementarity or substitutability between different types of innovation, we use the complementarity approach $[9,10]$, an approach that has recently been used in empirical studies on innovation and is becoming increasingly popular (e.g., Reference $[6,11]$ ). This complementarity approach allows us to check if the interaction between two types of innovation increases or decreases the final result pursued; that is, the joint final result may be higher or lower than the sum of the individual contributions of each innovation implemented. If the final result is higher than the sum of the corresponding individual contributions, it is said that the innovations implemented are complementary. On the contrary, if the final result is lower, then it is said that the innovations analysed are substitutes. Knowing this information in advance is vital since it allows companies to design the cocktail of types of innovation that are more convenient.

Now, in the complementarity approach, the relationship between variables is tested pairwise [12], so the number of tests to be executed depends on the number of variables of which the interaction is to be studied. For example, if two variables are analysed, it is only necessary to run one complementarity test. However, if there are three variables, it will be necessary to perform six complementarity tests, since there are three pairs of different variables in a set of three variables, and there are two alternative possibilities in each pair, depending on whether the third variable that does not belong to the analysed pair is present. Obviously, if there are four variables for which the complementarity is to be analysed, it will be necessary to carry out a total of twenty-four complementary tests. Therefore, as the extent of the number of variables whose complementarity is analysed increases, the number of complementary tests that must be undertaken increases by a geometric proportion. This provokes very extensive studies at the same time, which makes the corresponding analysis of complementarity difficult and enormously obscure due to the multiple interrelations that simultaneously have to be considered. For this reason, papers that address the complementarity analysis of more than three variables are unusual. Most complementary studies are carried out on three variables. Generally, if there are more than three variables, the complementarity analysis focuses on the two variables of greatest interest, while the remaining variables are transformed into a single variable (e.g., References $[6,10])$.

This study focuses on the Spanish manufacturing sector. Therefore, the two variables of greatest interest are product innovation and process innovation since product innovation and process innovation is usually associated with the manufacturing sector (e.g., Reference [13]). Therefore, in this study, organizational innovation and marketing innovation are subsumed into a single class called non-technological innovation. Accordingly, we conduct a complementarity analysis using the product innovation, process innovation, and non-technological innovation variables.

To respond to the two proposed objectives, this paper is divided into the following sections. In the next section, we establish the theoretical background and propose the corresponding hypotheses. Next, we describe the source of the data used, define the variables, and detail the methodology employed. In the subsequent section, we present and discuss the results. Finally, in the last section, we present the conclusions. 


\section{Theoretical Background and Hypotheses}

The objective of this study is to explore the extent to which different types of innovation (product, process, and non-technological) contribute to the achievement of the environmental objectives pursued by companies (environmental performance). We are also interested in analysing whether the different combinations of these types of innovation produce positive synergies (complementarity) or negative synergies (substitutability). Knowing in advance which combinations of types provide substitutive results is crucial since this knowledge can be used to avoid those combinations of innovation types that reduce environmental performance.

\subsection{The Literature and Hypotheses on the Influence of the Types of Innovation on Environmental Performance}

In the field of environmental economics literature, there are two basic lines of research on the relationship between environmental innovation and performance, depending on whether the focus is on business performance or environmental performance. On the one hand, the studies that explore the relationship between environmental innovation and business performance report contradictory results. There is empirical research that points out that environmental innovation is too costly, which is why business performance tends to decrease as investments in environmental innovation increase (e.g., References [14-16]). However, there is also a smaller number of studies that support a positive relationship between environmental innovation and business performance (e.g., Reference [17]). The dilemma is as follows [18]: 'is the environment a "strategic competitive factor", such as from the "Porter point of view" [19-21], or is it a "luxury good", such as from the "Wagner point of view" [22,23]?' On the other hand, the second basic line of research analyses the relationship between environmental innovation and environmental performance. In this second line, studies confirm the existence of a positive and significant relationship between environmental innovation and environmental performance [24,25].

This study focuses on the second line of research, that is, on the relationship between environmental innovation and environmental performance. However, it does so from a barely treated perspective, exploring the individual and simultaneous influence of different types of innovation (product, process, and non-technological innovation) on environmental performance. While the extant studies focus on exploring the individual influence of different types of innovation on environmental performance, little attention is paid to analysing all types of innovation jointly and no attention is paid to the interactions between these different types of innovation.

Product innovation in the environmental context has a fundamental objective: the design or development of a product that is new or significantly improved and that contributes to the reduction of environmental risk. This can occur due to one or more of the following causes: it uses fewer polluting materials, less material is used and less energy is consumed in its production, or the new product is easy to recycle, reuse, and decompose [14,26,27].

In the literature on environmental innovation, there are studies that confirm the relationship between environmental product innovation and performance (e.g., References [28,29]). In the specific field of environmental performance, there are studies that indicate that product design modifications contribute to the improvement of energy efficiency [30] and that product packaging with biodegradable materials contributes to generating a lower environmental impact [31]. Likewise, other authors point out that environmental product design is positively associated with environmental performance [32]. Therefore, given the above arguments, we intuit that there is a positive and significant relationship between product innovation and environmental performance, and we propose the following hypothesis: 
Hypothesis 1. Product innovation has a positive and significant influence on environmental performance.

Environmental process innovation aims at the design and development of new or modified production equipment, together with methods and procedures that minimize the environmental impact [26,33].

The manufacturing industry is considered to be one of the sectors that consumes more resources and generates more pollution than others [34]. Therefore, this industry offers a wide margin for the implementation of innovative strategies that lead to an improvement of the environmental impact [25]. The innovation strategy that is most linked to cost reduction is process innovation [35]. Therefore, environmental process innovation is the most important component of the set of environmental innovation types available [25]. However, the literature on environmental process innovation is very scarce [36].

Environmental process innovation makes it possible to reconcile the objective of reducing costs and reducing the environmental impact. Some studies find a strong link between process innovation and sustainability engagement [37]. However, since process innovation plays a very important role in the viability of companies, in the analysis of their influence on environmental performance, it is necessary to consider three vectors: the level of profitability (productivity), the age of the companies (young companies versus mature companies), and/or the degree of use of flexible technologies (traditional technologies versus flexible technologies).

The primary objective of companies is to survive, that is, to have economic viability [38]. Therefore, all their strategic and operational decisions must take this premise into consideration. Often though, the economic viability of the companies conflicts with other objectives, the persecution of which, in certain circumstances, deteriorates the companies' bases of profitability. Sometimes this happens to companies that pursue high environmental performance as a result of pressure from the corresponding governments and stakeholders. If the profitability of these companies is not good, the pursuit of environmental objectives can end up making the business profitability negative. Given that one of the main sources of companies' profitability is innovations [39], companies with profitability problems tend to use these innovations in defence of their economic viability, delaying their use in achieving environmental objectives [40], mainly in times of strong economic recession [41]. In fact, the literature on environmental innovation recognizes that companies with better economic/financial performance develop more environmental initiatives (e.g., References [18,42]). Therefore, when companies have a poor positive or negative rate of return, it is expected that the relationship between process innovation and environmental performance will be negative.

On the other hand, we must bear in mind that the resources and capacities accumulated by companies are related to their age [43] and that the performance and many of the strategic decisions that companies make are influenced by such a variable [44]. As age increases, companies tend to exploit their existing technological competencies rather than exploring new and unfamiliar technologies [45]. That is, young companies rely more on product innovation, while mature companies rely more on process innovations. Therefore, with the passage of time, companies focus on standardized technologies and the routinization of processes [46] and set their priority on economic survival [38]. As a result, they devote fewer resources and capacities to the development of environmental activities. One study analyses the influence of process innovation on the environmental performance of companies, taking into account the passage of time. The study focuses on companies belonging to Spanish science and technology parks [37]. This study verifies that, with the passage of time, the relationship between process innovation and environmental sustainability engagement becomes negative.

On the other hand, the influence of process innovation on business performance and environmental performance also depends on the kind of technology (traditional or flexible) that is used in the production process. The traditional technology is too rigid and does not allow companies to attend effectively and efficiently to more than one objective, simultaneously. However, modern 
flexible technologies are capable of concurrently meeting different objectives, some of which are contradictory when using traditional process technologies. Therefore, the use of flexible process technologies facilitates companies' simultaneous pursuit of economic benefits and environmental benefits, without endangering their future economic viability. On the contrary, companies that use traditional process technology may find it difficult to pursue economic benefits and environmental benefits at the same time. As their survival depends on achieving high business performance, they postpone the pursuit of environmental benefits. Obviously, in the aforementioned circumstances, the relationship between process innovation and environmental performance may be negative.

In general, Spanish companies have an average level of productivity that is lower than companies in other advanced European countries [47] and exhibit a low level of use of flexible technologies [7,48]. Therefore, according to the previous arguments, it is expected that, among Spanish manufacturing companies, the relationship between process innovation and environmental performance will be negative. The above arguments lead us to formulate the following hypothesis:

Hypothesis 2. Process innovation has a negative and significant influence on environmental performance.

The contribution of organizational environmental innovation to the achievement of environmental benefits is poorly studied. However, some studies indicate that this relationship is positive. For example, there are authors who defend the idea that a firm's organizational capacity positively influences its environmental innovation intensity [49,50] as well as its possession of a strong organizational knowledge base [51]. In general, the innovation literature recognizes that organizational capability has a positive influence on environmental performance [52-54].

Marketing capabilities are related to the knowledge of the competition and customers as well as the ability to segment markets, develop effective advertising campaigns, set prices, and integrate with the other functions of the company [55]. These abilities are difficult to imitate; therefore, they are an invaluable source of competitive advantage [56]. For this reason, many authors consider that marketing capabilities are one of the key functions of companies (e.g., Reference [57]). Different studies analyse the relationship between marketing capabilities and performance. In general, these studies find that this relationship is positive and significant (e.g., Reference [58]).

However, in the environmental field, the relationship between marketing capabilities and environmental performance is barely studied; very few empirical studies analyse this relationship. Two recent empirical studies have focused on this subject. On the one hand, Reference [59] find that marketing capabilities significantly affect environmental management practices, which in turn leads to better environmental performance. On the other hand, Reference [60] find that marketing capacity significantly moderates the relationship between environmental regulation and environmental innovation strategy, which leads to the achievement of greater environmental performance.

As the literature supports the assertion that organizational and marketing innovation (non-technological innovation) have a positive influence on environmental performance, we propose the following hypothesis:

Hypothesis 3. Non-technological innovation has a positive and significant influence on environmental performance.

\subsection{Hypotheses about the Complementarity of Innovation Types in Relation to Environmental Performance}

In the economic literature, there is a broad and intense debate about the synergistic effects that occur when product innovation and process innovation are implemented simultaneously. On this subject, there are two conflicting views. On the one hand, the product-process matrix (PPM) framework argues that the relationship between the two types of innovation is of a substitute nature. On the other hand, the new PPM version considers that the nature of this relationship is complementary. 
The PPM is proposed for the first time by References [61,62], extending and completing the previous contributions of References $[63,64]$. The PPM framework states that, when process innovation has a greater weight, the product range and production costs will reduce gradually. That is, for this approach, there is a direct trade-off between product innovation and process innovation so that changes in the relative weights of the two types of innovation lead to changes in the efficiency-product range' mix. Consequently, if product innovation gains weight, customization increases and efficiency decreases; on the other hand, if the one that gains weight is process innovation, we can expect an increase in efficiency and a decrease in customization. In short, for the PPM, product innovation and process innovation are substitutes.

The empirical studies about the PPM framework are not very abundant, and their results reflect a certain degree of contradiction. Thus, some empirical investigations endorse the PPM postulates (e.g.,'Reference [65]), while others do not endorse them (e.g., Reference [66]).

On the other hand, it must be underlined that, with the increasing implementation of new processing technologies (e.g., computer-integrated technology) and new product designs (e.g., computer-aided design), many authors find that the trade-offs between product innovation and process innovation have changed: it is now common to find combinations of product innovation and process innovation with high levels of customization and high levels of efficiency simultaneously (e.g., Reference [67]). In other words, the incorporation of new product and process technologies transforms substitute relationships into complementary relationships. Therefore, the new PPM version states that the simultaneous implementation of product innovation and process innovation produces a result that is greater than the sum of the corresponding individual contributions.

In consequence, in the new PPM version, two different types of interaction between product innovation and process innovation are deduced:

(a) If the use of traditional technologies prevails in the productive process, the relationship between product innovation and process innovation is uncertain, depending on the objectives pursued by the company. If the company fundamentally pursues efficiency, the relationship can be complementary. On the contrary, if the company pursues more than one objective simultaneously (for example, efficiency and the improvement in the environmental impact), the relationship can be substitutive, depending on the level of profitability and economic sustainability enjoyed by the company. In a scenario of intense economic and financial precariousness, the company will concentrate all its efforts on improving its efficiency and not allocate resources to environmental improvement. This happens because the traditional technology is a single lane insofar as it does not allow opposing objectives to be met satisfactorily and simultaneously. Pursuing contrary objectives simultaneously can seriously damage efficiency and jeopardize the economic viability of the company.

(b) On the contrary, if the use of flexible technologies prevails in the productive process, the relationship between product innovation and process innovation can be complementary since this kind of technology allows for the simultaneous achievement of different objectives without the loss of efficiency.

In view of the foregoing, it can be deduced that, in productive environments that use flexible technologies, the simultaneous implementation of both types of innovation is not contraindicated. However, in productive environments that prefer traditional technologies, the simultaneous implementation of both types of innovation can be problematic. In this case, the implementation of one or the other kind of innovation depends on the objective that is prioritized since, in this kind of environment, efficiency, customization, and environmental improvement can hardly be achieved simultaneously.

In the Spanish manufacturing sector, there is a predominance of small and medium-sized companies with low R\&D expenditures that prefer to use traditional low technology [68]. Consequently, Spain is a moderate innovator [69]. Therefore, in accordance with the prescriptions of the 
new PPM version, we intuit that, in the Spanish manufacturing sector, the relationship between product innovation and process innovation is substitutive; that is, the simultaneous implementation of strategies that pursue product innovation and process innovation decreases environmental performance. Consequently, in accordance with the literature review conducted and the structure of Spanish manufacturing companies, we propose the following hypothesis:

Hypothesis 4. The relationship between product innovation and process innovation is substitutive with respect to environmental performance.

A large part of the innovation literature considers that technological innovation is a driver of non-technological innovation (e.g., Reference [70]). However, there are also authors who point out that, in many cases, non-technological innovations precede technological innovations (e.g., Reference [71]). In any case, there is no doubt that both types of innovation are usually implemented jointly, which results in the two kinds of innovation influencing each other [72], increasing the likelihood that the innovation process will be successful [73]. In this study, we are interested in analysing the benefits or damages that are derived from the joint implementation of product innovation and non-technological innovation.

Non-technological innovation is made up of organizational innovation and marketing innovation; therefore, the relationship between product innovation and non-technological innovation will be determined by the weight of organizational innovation and marketing innovation in the non-technological innovation variable.

The influence of organizational innovation on environmental innovation is rarely studied (e.g., References $[49,50])$. However, in the environmental context, we do not know of any studies that address the analysis of the environmental benefits derived from the simultaneous implementation of product innovation and organizational innovation. In the context of classical innovation, research does exist, although it is relatively recent. Thus, for example, Reference [74] finds that the joint implementation of organizational innovation and product innovation has a positive impact on firms' return on sales, while Reference [6] finds that this relationship is complementary in France and statistically not significant in the UK. On the other hand, in the context of the Spanish manufacturing sector, Reference [7] reports a non-relation between the two types of innovation while Reference [75] finds that the production process performance increases when companies adopt organizational and technological innovation simultaneously. Therefore, these studies suggest that the relationship between product innovation and organizational innovation is complementary or independent but in no case substitutive.

With regard to the relationship between product innovation and marketing innovation, we must bear in mind that product environmental innovation aims to achieve new products with the lowest possible environmental impact or significantly improved products that have a lower environmental impact than the products that they replace. However, along with the need to create new products that contribute to the sustainability of the environment, the companies that manufacture these products must also be sustainable; that is, they must be able to allow customers to buy these new products at a price that makes the viability of the companies possible. Marketing innovation can decisively help this to happen, as it can help customers to buy the new products that the company offers. Likewise, innovation in marketing can be a guide for the development of product innovation, helping companies to define a more competitive pricing policy that meets the objective of cost reduction [76] as well as achieving better recognition of their customers' needs [77]. Therefore, all these arguments are clear indications that product innovation and marketing innovation reinforce each other, so their relationship should be complementary. In this sense, in the context of the service sector of the Spanish economy, it is found that technological innovation and innovation in marketing are complementary [78].

Since it can be concluded that both organizational innovation and marketing innovation are likely to be complementary to product innovation, we propose the following hypothesis: 
Hypothesis 5. The relationship between product innovation and non-technological innovation is complementary with respect to environmental performance.

Innovation is not only the development of new products and processes (technological innovation) but also the adoption and/or development of new forms of organization and marketing (non-technological innovation) [79]. Technological and non-technological innovation are interdependent [80] insofar as it is precisely non-technological innovation that facilitates the further development of technological innovation [74]. It is currently recognized that different types of innovation influence each other, which is why many authors consider that their joint implementation provides a greater performance than the sum of their individual implementations [72,81]. Consequently, many authors consider that future research should pay greater attention to the impact that the simultaneous implementation of technological innovation and non-technological innovation has on the performance of companies [74,82].

In this sense, in this section, we try to reflect on whether the joint implementation of process innovation and non-technological innovation generates positive synergies (complementarity) or negative synergies (substitutability) for environmental performance. To achieve this, we must take into account the context (the Spanish manufacturing sector) and the role played by both organizational innovation and marketing innovation in relation to process innovation.

Process innovation and organizational innovation are the most significant innovation strategies [83]. Likewise, the literature on innovation recognizes that organizational innovation plays an important role in the innovation process (e.g., Reference [84]). The main objective of both types of innovation is to reduce costs $[35,85]$. Therefore, the joint implementation of both types of innovation can generate complementarity or substitutability, depending on whether they reinforce each other or cancel each other out, a question that largely depends on the context. For example, the results of complementarity/substitutability relationships between product innovation, process innovation, and organizational innovation in France and the UK are different [6].

The Spanish manufacturing sector is formed mainly of small companies [86] with scarce financial resources to undertake costly innovations. In addition, it should be emphasized that, in general, the implementation of organizational innovations, although not initially requiring large investments, consumes resources [87]. Therefore, small companies are not always able to implement the two types of innovation jointly, so they are forced to opt for the implementation of a single type of innovation, especially when both types pursue the same objective of reducing costs. Therefore, the joint implementation of process innovation and organizational innovation may lead to trade-offs in terms of resources and, consequently, possibly generate substitution relations.

However, in non-technological innovation, we must also consider the role that marketing innovation plays since companies must conveniently integrate the product, process, organizational, and marketing innovation [88].

Marketing innovation involves the implementation of significant improvements in some of the marketing elements, such as product, price, promotion, distribution, and market. Therefore, marketing innovation refers to changes in the context in which goods are introduced to the market, taking into account the consumers' needs, in terms of either perceived value or price.

It is not enough to create new products (product innovation) or reduce the production costs of existing products (process innovation). It is also necessary to adopt new products or new prices to the unmet needs of the customers. In this sense, marketing innovation seeks to convince customers to perceive an increase in value if they consume the new product, which allows the offering company to obtain the benefits derived from the possession of a differentiation advantage or to contribute, for example, to reducing the corresponding distribution costs, helping to build a cost advantage [89]. 
Designing, developing, and marketing a new product requires the deployment of significant marketing capacity since it is necessary to have in-depth knowledge of the unmet needs of potential customers and convince these potential customers to buy the new product [90]. Therefore, the existence of important positive synergies (complementarities) in relation to environmental performance can be expected from the relationship between product innovation and marketing innovation. However, in most cases, the achievement of market benefits derived from the implementation of process innovations that contribute to the reduction of production costs has a much lower demand in terms of the deployment of marketing capabilities, since, in this case, it concerns existing products that have previously made the necessary investments to penetrate the market. Consequently, the existence of high positive synergies between process innovation and marketing innovation cannot be expected. Even in this case, it is likely that there will be no statistically significant relationship between process innovation and marketing innovation.

In the complementarity approach, complementarity tests are carried out between pairs of variables. When the complementarity between process innovation and non-technological innovation is analysed, two tests need to be carried out: one for the companies that do not implement product innovation and the other for the companies that do implement product innovation. Taking into account that the non-technological innovation variable is formed by organizational innovation and marketing innovation, and being aware of the synergies expected and previously commented on between these two types of innovation and process innovation, we propose the following hypothesis:

Hypothesis 6. The relationship between process innovation and non-technological innovation with respect to environmental performance is: (a) substitutive among companies that do not implement product innovation; (b) non-existent between the companies that do implement product innovation.

\section{Data, Variables, and Methodology}

\subsection{Data}

We use the 2013 Technological Innovation Panel (PITEC) data for Spanish manufacturing firms. The PITEC is based on the Community Innovation Survey (CIS) database. After removing the observations with missing values we obtain 4543 observations.

CIS is one of the most used datasets in innovation studies. There are many empirical studies that have used data from the CIS (e.g., References [91,92]). Recently, the data from the CIS are also being used to carry out studies on environmental innovation (e.g., References [92-95]). Two of the most important advantages that have the use of data from the CIS are the important volume of observations and the confidence on the reliability of your data [91], as the classic problems of interpretability, reliability, and validity are considered as negligible (e.g., References [91,96]). However, the use of the CIS data also has drawbacks. The data collected are self-reported by the respondents, so they may exhibit a certain degree of subjectivity [92]. However, Reference [97] points out that the subjective measures of innovation surveys tend to be consistent with the corresponding objective measures of innovation.

\subsection{Variables}

Our dependent variable, environmental performance, is based on the importance that companies attach to a set of environmental objectives. The PITEC asked the companies for the degree of importance of the following firm innovation objectives (valued between 0 and 3, depending on their importance): using less material per unit produced; using less energy per unit produced; exerting a lower impact on the environment; and complying with the requirements for the environment. These objectives constitute some of the most important environmental benefits that are derived from the implementation of different types of innovation [98] and 'are therefore essential to help in the assessment of the 
private R\&D environmental performance in Europe' [98]. In addition, these environmental objectives (benefits) constitute the benchmarks of different indicators that try to measure the environmental performance [2]. Likewise, these benchmarks of environmental performance are also used as an indicator of eco-innovation (e.g., Reference [99]), insofar as environmental innovation is usually defined as 'actions taken by individuals or teams that improve the environmental performance of companies' [100].

The independent variables of interest are product innovation, process innovation, and non-technological innovation. To implement complementarity tests it is necessary to define these variables in mode $(0 / 1)$.

Finally, this study uses four variables that act as contextual and control variables, the relevant role of which is recognized in the literature on innovation and business performance.

In general, the literature on innovation recognizes that the innovation capacity of companies is based not only on their own resources and ability to use these resources but also on the opportunities to obtain new solutions, technologies, concepts, and ideas created by other entities that operate in the environment [101]. From the information provided by the PITEC, we construct the openess variable.

Companies that sell in international markets are subject to greater competitive pressure [102] since they have to satisfy very complex heterogeneous needs. One of these needs concerns the existence of demanding environmental regulations, an issue that pushes exporting companies to implement environmental innovations [103]. Therefore, in this study, we use Export as a proxy variable for competitive pressure, a form of pressure that has an important influence on the innovative activity of the company and its environmental performance [104].

Likewise, it is assumed that companies belonging to a group are more likely to achieve better levels of performance than independent firms [105] and have better access to the internal information sources of the group that can improve their corresponding innovation capacities [106]. In this sense, the PITEC provides direct information on the belonging of the company to a group.

Size constitutes one of the critical variables regarding the innovative performance of companies [107], although the sign of its influence on environmental innovation is uncertain [108]. The PITEC provides the number of employees of companies.

Schumpeter places innovation at the center of his first great contribution [109] and shows that the role of innovation is fully endogenize [110]; that is, it is not an exogenous variable that can be defined outside the model [111] but is internally induced by needs and pressures [112]. Consequently, we consider the three innovation variables that we incorporate into our model (product, process, and non-technological innovation) as potentially being endogenous. The complementarity approach requires that the variables of which the complementarity is to be evaluated are defined in the $(0 / 1)$ mode and that from these variables all possible exclusive combinations are defined. As there are three variables of interest (product, process, and non-technological innovation), there will be eight exclusive combinations, of which only one will not represent any technological option (in particular, it will be the variable 000 that represents the option in which no type of innovation is present). Therefore, in our model, there are seven exclusive potentially endogenous combinations.

To control this potential endogeneity, we use the two-stage least squares (2SLS) method as an instrumental variable estimator. This method requires the use of at least as many instrumental variables as potentially endogenous variables exist in the model. Therefore, we include those variables that are identified in the literature on innovation as being important instrumental variables and that are available in the Community Innovation Survey database (e.g., References $[113,114])$ : RD activities, training, RD subsidy, RD internal capacity, training capacity, innovation capacity, and cooperation with clients, suppliers and competitors.

A precise definition of how the variables were constructed can be found in Table 1. 
Table 1. The variable definitions.

\begin{tabular}{|c|c|c|}
\hline Variable Name & Variable Construction & Acronyms \\
\hline Environmental performance & $\begin{array}{l}\text { Sum of the scores about the importance of the following } \\
\text { firm innovation objectives (a number between } 0 \text { (not } \\
\text { used) and } 3 \text { (high)): using less material per unit } \\
\text { produced; using less energy per unit produced; exerting } \\
\text { a lower impact on the environment; complying with the } \\
\text { requirements for the environment. Rescaled between } 0 \\
\text { (not used) and } 1 \text { (high). }\end{array}$ & EP \\
\hline Product innovation & The firm introduces a new product $(0 / 1)$ & PDTI \\
\hline Process Innovation & The firm introduces a new process $(0 / 1)$ & PCSI \\
\hline Non-technological innovation & $\begin{array}{l}\text { The company introduces or modifies at least one of the } \\
\text { following practices or methods: new business practices } \\
\text { in the organization of procedures; new methods of } \\
\text { organization of responsibilities and decision making; } \\
\text { new methods of organization of external relations with } \\
\text { other companies or public institutions; significant } \\
\text { changes in product design or packaging; significant } \\
\text { changes in product placement; significant changes in } \\
\text { product promotion; and significant changes in pricing } \\
(0 / 1)\end{array}$ & NTI \\
\hline Openess & $\begin{array}{l}\text { Sum of the scores about the importance of the following } \\
\text { sources for the innovation process (a number between } 0 \\
\text { (not used) and } 3 \text { (high)): Internal; Suppliers; Clients; } \\
\text { Competitors; Consultants; Universities; Public research } \\
\text { centres; Technology centres; Fairs and exhibitions; } \\
\text { Journals; Professional associations. Rescaled between } 0 \\
\text { (not used) and } 1 \text { (high). }\end{array}$ & OPENESS \\
\hline Export intensity & Export share in total firm sales & EXPORT \\
\hline Group & The firm belongs to a group $(0 / 1)$ & GROUP \\
\hline Size & The $\log$ of the number of employees & SIZE \\
\hline RD activities & $\begin{array}{l}\text { The firm conducts internal R\&D activities systematically } \\
(0 / 1) \text {. }\end{array}$ & RDA \\
\hline Training & The firm offers formal training to its workers $(0 / 1)$. & TRAINING \\
\hline RD subsidy & $\begin{array}{l}\text { The firm receives R\&D subsidies from one or more of the } \\
\text { following programs: Spanish regions, Spanish state, } \\
\text { European Union, and the Framework program }(0 / 1) \text {. }\end{array}$ & RDS \\
\hline RD internal capacity & $\begin{array}{l}\text { The relationship between the internal R\&D expenditures } \\
\text { and the total sales of the firm. }\end{array}$ & RDIC \\
\hline Training capacity & $\begin{array}{l}\text { The relationship between training expenditures and the } \\
\text { total sales of the firm. }\end{array}$ & TC \\
\hline Innovation capacity & $\begin{array}{l}\text { The relationship between total innovation expenditures } \\
\text { and the total sales of the firm. }\end{array}$ & IC \\
\hline $\begin{array}{l}\text { Cooperation with clients, } \\
\text { suppliers and competitors }\end{array}$ & $\begin{array}{l}\text { The firm cooperates with at least one of the following } \\
\text { types of partners: clients, suppliers, and competitors } \\
(0 / 1) \text {. }\end{array}$ & CCSC \\
\hline
\end{tabular}

\subsection{Methodology}

The theory of supermodular games, based on the mathematical model developed by Reference [9], allows us to formalize the necessary conditions to understand the relationship of complementarity/substitutability between two variables. Formally, it is said that two activities are complementary if the sum of the benefits that result from the implementation of one or the other is less than the benefits that are obtained from their joint implementation [115].

To implement the approach of complementarity proposed by Reference [10], it is necessary to define an objective function. Suppose that there are two activities, $X_{i}$ and $X_{j}$, and $Z$ is a vector of exogenous variables in an objective function $F\left(X_{i}, X_{j}, Z\right)$. Assume that $X_{i}$ and $X_{j}$ are dichotomous 
choices that take the value 1 if they are adopted by the firm and the value 0 if they are not. The complementarity approach regresses the objective pursued on a unique combination of the two activities considered and on the vector of exogenous variables:

$$
F\left(X_{i}, X_{j}, Z\right)=\beta_{00}\left(1-X_{i}\right)\left(1-X_{j}\right)+\beta_{10} X_{i}\left(1-X_{j}\right)+\beta_{01}\left(1-X_{i}\right) X_{j}+\beta_{11} X_{i} X_{j}+\beta_{z} Z+e
$$

where $\beta_{11}$ measures the cross-partial returns of choosing $X_{i}$ and $X_{j}$ jointly; $\beta_{10}$ for choosing only $X_{i}$; $\beta_{01}$ for choosing only $X_{j}$; and $\beta_{00}$ for choosing none of them. Therefore, we can say that the objective function $F\left(X_{i}, X_{j}, Z\right)$ is supermodular and that $X_{i}$ and $X_{j}$ are complementary if [116]

$$
\beta_{11}+\beta_{00}-\beta_{10}-\beta_{01}>0
$$

Obviously, it can be said that the objective function $F\left(X_{i}, X_{j}, Z\right)$ is submodular and that $X_{i}$ and $X_{j}$ are substitutes if [116]

$$
\beta_{11}+\beta_{00}-\beta_{10}-\beta_{01}<0
$$

The number of inequalities that will need to be contrasted will depend on the number of variables for which complementarity is sought [12]. In our particular case, since there are three variables to consider, the number of restrictions to be tested will be six. For example, if we want to test for the complementarity between product innovation and process innovation, we have to test the two following non-trivial inequalities:

$$
\begin{gathered}
\beta_{110}+\beta_{000}-\beta_{100}-\beta_{010}>0 \text { (between companies not engaged in non-technological innovation) } \\
\beta_{111}+\beta_{001}-\beta_{101}-\beta_{011}>0 \text { (between companies engaged in non-technological innovation) }
\end{gathered}
$$

In this study, we use two models. In model I, we incorporate all the previously defined variables. The determination of the coefficients of these variables will allow us to test Hypotheses 1, 2, and 3. In model II, we substitute the product innovation, process innovation, and non-technological innovation variables with eight exclusive profiles of these three variables. For example, the variable 110 represents the unique combination of companies that use product innovation and process innovation but do not use non-technological innovation. The coefficients of the eight exclusive variables will be used to contrast Hypotheses 4, 5, and 6.

However, our models incorporate potentially endogenous variables. In model I, product innovation, process innovation, and non-technological innovation are potentially endogenous. In model II, there are seven potentially endogenous variables (the seven exclusive combinations with the technological content of the eight possible combinations of product innovation, process innovation, and non-technological innovation).

When there are endogenous variables, the OLS estimators are inconsistent. Therefore, it is necessary to control the potential endogeneity. Consequently, we use the two-stage least-squares (2SLS) method as an instrumental variable estimator, which allows us to control the endogeneity and obtain consistent estimators.

Our econometric strategy is to perform endogeneity tests to distinguish which variables are endogenous and which are exogenous. According to the results, we return to specifying the model in successive steps and estimate the corresponding coefficients. In the last step, the variables that are definitely endogenous are defined. The estimated coefficients of the last step will be used to perform the corresponding hypothesis tests. Likewise, when the number of instrumental variables is greater than the number of potentially endogenous variables in the successive steps, we will perform an overidentification test, and, if necessary, we will proceed to redefine the set of instrumental variables that best represents the new set of potentially endogenous variables. 


\section{Results and Discussion}

The descriptive statistics of the variables used in this study are reflected in Table 2.

Table 2. The descriptive Statistics.

\begin{tabular}{cccccc}
\hline Variables & Nature of the Variable & Min. & Max. & Mean & Standard Deviation \\
\hline Environmental performance & Continuous & 0.00 & 1.00 & 0.33 & 0.35 \\
Product innovation & Binary (0/1) & 0 & 1 & 0.44 & 0.50 \\
Process innovation & Binary (0/1) & 0 & 1 & 0.40 & 0.49 \\
Non-technological innovation & Binary (0/1) & 0 & 1 & 0.46 & 0.50 \\
Openess & Continuous & 0.00 & 1.00 & 0.28 & 0.27 \\
Export & Continuous & 0.00 & 1.00 & 0.33 & 0.33 \\
Group & Binary (0/1) & 0 & 1 & 0.42 & 0.49 \\
Size (Number of employees) & Continuous & 1 & 8670 & 147.08 & 421.96 \\
$\mathbf{1 1 1}$ & Binary (0/1) & 0 & 1 & 0.21 & 0.41 \\
$\mathbf{1 0 0}$ & Binary (0/1) & 0 & 1 & 0.09 & 0.28 \\
$\mathbf{0 1 0}$ & Binary (0/1) & 0 & 1 & 0.06 & 0.24 \\
$\mathbf{0 0 1}$ & Binary (0/1) & 0 & 1 & 0.10 & 0.29 \\
$\mathbf{1 1 0}$ & Binary (0/1) & 0 & 1 & 0.06 & 0.24 \\
$\mathbf{1 0 1}$ & Binary (0/1) & 0 & 1 & 0.08 & 0.27 \\
$\mathbf{0 1 1}$ & Binary (0/1) & 0 & 1 & 0.08 & 0.26 \\
$\mathbf{0 0 0}$ & Binary (0/1) & 0 & 1 & 0.33 & 0.47 \\
\hline
\end{tabular}

Of the firms, in average terms, $33 \%$ implement procedures that aim to reduce their environmental impact. This figure coincides with that obtained by another study on the French economy [5]. However, in this study, the figures on the implementation of different types of innovation are manifestly divergent between the two countries. In Spain, product innovation and process innovation are introduced by $44 \%$ and $40 \%$, respectively, while the corresponding figures for France are $67 \%$ and $61 \%$, respectively. Likewise, in Spain, $46 \%$ of companies implement non-technological innovation, while, in France, 70\% of companies carry out organizational innovation. In light of these results, it is clear that Spain is a moderately innovative country [69].

In relation to the descriptive statistics of the eight exclusive combinations obtained from the three types of innovation analysed in this study, we find that the most-used combination is the absence of any type of innovation (33\%), followed by the combination that reflects the use joint of the three types of innovation (21\%) and the implementation of non-technological innovation alone (10\%). The last result supports the assertion that non-technological innovation plays a very important role among innovative firms [2].

Table 3 shows the estimated coefficients of model I, allowing us to analyse the influence of the three types of innovation on environmental performance and, consequently, to test Hypotheses 1, 2, and 3.

Table 3. Model I. The results of the regressions for environmental performance.

\begin{tabular}{ccc}
\hline Variables & Step 1 & Step 2 \\
\hline \multirow{2}{*}{ Product innovation } & 0.246 & -0.141 \\
& $(0.197)$ & $(0.094)$ \\
\hline \multirow{2}{*}{ Process innovation } & -0.465 & $-1.105^{*}$ \\
& $(0.427)$ & $(0.606)$ \\
\hline Non-technological & 0.882 & $2.160^{* *}$ \\
innovation & $(0.790)$ & $(0.999)$ \\
\hline Openess & $0.468^{* * *}$ & $0.492^{* * *}$ \\
& $(0.088)$ & $(0.186)$ \\
\hline
\end{tabular}


Table 3. Cont

\begin{tabular}{ccc}
\hline Variables & Step 1 & Step 2 \\
\hline \multirow{2}{*}{ Export } & 0.018 & 0.064 \\
& $(0.034)$ & $(0.052)$ \\
\hline \multirow{2}{*}{ Group } & 0.000 & -0.003 \\
& $(0.017)$ & $(0.036)$ \\
\hline \multirow{2}{*}{ Size } & 0.015 & -0.009 \\
& $(0.023)$ & $(0.041)$ \\
\hline \multirow{2}{*}{ Constant } & $-0.151^{*}$ & $-0.289^{* *}$ \\
& $(0.090)$ & $(0.126)$ \\
\hline Model: Wald chi2 & $1593.70^{* * *}$ & $350.722^{* * *}$
\end{tabular}

Note: Standard errors are in parentheses. ${ }^{*}$ Significant at $10 \%$; ${ }^{* *}$ Significant at $5 \%$; ${ }^{* *}$ Significant at $1 \%$.

Regarding Hypothesis 1, we found that product innovation has a negative influence on environmental performance, although it is not statistically significant. Therefore, Hypothesis 1 is not supported. This result is similar to that obtained by Reference [14], with the difference that in that study the influence of product innovation is positive, while in ours it is negative. This difference is probably due to the fact that our analysis uses environmental performance as a dependent variable and the study by Reference [14] uses firm performance. Other studies on Spanish companies have also found that environmental proactive initiatives have no statistically significant influence on financial performance [117].

Regarding Hypothesis 2, we find that process innovation has a negative and statistically significant influence on environmental performance. This result supports Hypothesis 2. Similar behaviour is found in a recent study among mature companies that operate in a science and technology park [37].

In our opinion, the negative association of product and process innovation with environmental performance has its origin in the important weakness that Spanish manufacturing companies exhibit on average, both in terms of size and in terms of financial performance. This forces them to dedicate most of their energy to fighting for their survival, so obtaining the maximum possible efficiency becomes a fundamental objective while the environmental objectives become secondary. In the same sense, some authors point out that, in certain situations, firm survival and economic sustainability become the main objectives of many companies [38].

We find a significant positive impact of non-technological innovation on environmental performance. This result supports Hypothesis 3. In this sense, some authors suggest (e.g., Reference [118]) that the implementation of product innovation and process innovation often involves the implementation of environmental management systems [119] and total quality management [120], which generally has a positive impact on environmental performance [121,122]. There are hardly any empirical studies that analyse the influence of non-technological innovation on environmental performance. One of these few studies, which focused on French companies, also found that new organizational methods and new ways of designing, packaging, and distributing products significantly reduce the energy used in products and the pollution that they cause and increase their recyclability [5].

Table 4 shows the endogeneity tests carried out in model I on the three potentially endogenous variables. In the first step, the endogeneity test rules out the endogeneity of the product innovation variable, so, in the estimation of the model in the second step, this variable becomes exogenous. The endogeneity tests carried out in the second step confirm that the endogenous variables in model I are process innovation and non-technological innovation. 
Table 4. Model I. The Durbin-Wu-Hausman endogeneity test.

\begin{tabular}{ccc}
\hline Variables & Step 1 & Step2 \\
\hline Product innovation & 0.887 & - \\
Process innovation & $4.7633^{* *}$ & $38.927 * * *$ \\
Non-technological innovation & $3.502 *$ & $93.544^{* * *}$ \\
\hline$*$ Significant at $10 \% ; *$ Significant at $5 \% ;{ }^{* * *}$ Significant at $1 \%$.
\end{tabular}

Table 5 shows the estimated coefficients of the two-stage least squares (2SLS) as the instrumental variables model (model II). Our goal is to perform complementary tests on the three innovations analysed. We are only interested in the coefficients of the eight unique combinations of the three types of innovation as these factors are essential to perform complementary tests.

Table 5. Model II. The results of the regressions for environmental performance.

\begin{tabular}{|c|c|c|c|c|}
\hline Variables & Step 1 & Step 2 & Step 3 & Estep 4 \\
\hline Openess & $\begin{array}{c}-3.387 \\
(37.975)\end{array}$ & $\begin{array}{c}0.094 \\
(0.403)\end{array}$ & $\begin{array}{c}0.836^{* * *} \\
(0.232)\end{array}$ & $\begin{array}{c}0.662^{* * *} \\
(0.045)\end{array}$ \\
\hline Export & $\begin{array}{c}0.457 \\
(4.941)\end{array}$ & $\begin{array}{c}0.031 \\
(0.072)\end{array}$ & $\begin{array}{l}-0.034 \\
(0.034)\end{array}$ & $\begin{array}{l}-0.022 \\
(0.016)\end{array}$ \\
\hline Group & $\begin{array}{c}0.357 \\
(3.187) \\
\end{array}$ & $\begin{array}{c}0.067 \\
(0.058) \\
\end{array}$ & $\begin{array}{l}0.053 \text { * } \\
(0.030)\end{array}$ & $\begin{array}{c}0.048^{* * *} \\
(0.016)\end{array}$ \\
\hline Size & $\begin{array}{l}-0.316 \\
(2.759)\end{array}$ & $\begin{array}{l}-0.108 \\
(0.142)\end{array}$ & $\begin{array}{l}-0.141 \\
(0.092)\end{array}$ & $\begin{array}{c}-0.096^{* *} \\
(0.039)\end{array}$ \\
\hline 111 & $\begin{array}{c}2.147 \\
(15.882)\end{array}$ & $\begin{array}{l}0.755^{*} \\
(0.404)\end{array}$ & $\begin{array}{c}0.480^{* * *} \\
(0.182)\end{array}$ & $\begin{array}{c}0.476^{* * *} \\
(0.097)\end{array}$ \\
\hline 100 & $\begin{array}{c}-9.244 \\
(99.382)\end{array}$ & $\begin{array}{c}-0.0415 \\
(0.973)\end{array}$ & $\begin{array}{l}0.282 * \\
(0.152)\end{array}$ & $\begin{array}{c}0.271^{* * *} \\
(0.080)\end{array}$ \\
\hline 010 & $\begin{array}{c}-13.158 \\
(132.708)\end{array}$ & $\begin{array}{l}-1.750 \\
(1.896)\end{array}$ & $\begin{array}{c}1.859 \\
(1.414)\end{array}$ & $\begin{array}{c}0.765^{* * *} \\
(0.199)\end{array}$ \\
\hline 001 & $\begin{array}{c}0.577 \\
(11.011)\end{array}$ & $\begin{array}{c}0.304 \\
(0.253)\end{array}$ & $\begin{array}{l}0.261 * \\
(0.138)\end{array}$ & $\begin{array}{c}0.216^{* * *} \\
(0.067)\end{array}$ \\
\hline 110 & $\begin{array}{c}-3.652 \\
(56.757)\end{array}$ & $\begin{array}{l}0.622 * \\
(0.359)\end{array}$ & $\begin{array}{c}0.402^{* *} \\
(0.165)\end{array}$ & $\begin{array}{c}0.391^{* * *} \\
(0.087)\end{array}$ \\
\hline 101 & $\begin{array}{c}25.218 \\
(249.027)\end{array}$ & $\begin{array}{c}2.833 \\
(1.834)\end{array}$ & $\begin{array}{l}-0.377 \\
(0.927)\end{array}$ & $\begin{array}{c}0.356^{* * *} \\
(0.085)\end{array}$ \\
\hline 011 & $\begin{array}{c}9.986 \\
(94.018) \\
\end{array}$ & $\begin{array}{c}1.458 \\
(1.359) \\
\end{array}$ & $\begin{array}{c}0.422 \text { ** } \\
(0.163)\end{array}$ & $\begin{array}{c}0.401^{* * *} \\
(0.086)\end{array}$ \\
\hline 000 & $\begin{array}{c}0.522 \\
(4.173)\end{array}$ & $\begin{array}{c}0.189 \\
(0.205)\end{array}$ & $\begin{array}{l}0.206^{*} \\
(0.124)\end{array}$ & $\begin{array}{c}0.154^{* * *} \\
(0.056)\end{array}$ \\
\hline Model: Wald chi2 & 11.76 & $965.68^{* * *}$ & $3740.59 * * *$ & $13,227.64^{* * *}$ \\
\hline
\end{tabular}

Note: Standard errors are in parentheses. * Significant at $10 \% ;{ }^{* *}$ Significant at $5 \%$; ${ }^{* * *}$ Significant at $1 \%$.

Table 6 shows the endogeneity tests carried out in model II on the seven potentially endogenous variables. 
Table 6. Model II. The Durbin-Wu-Hausman test of potentially endogenous variables.

\begin{tabular}{ccccc}
\hline \multirow{2}{*}{ Variables } & \multicolumn{4}{c}{ Durbin-Wu-Hausman Test } \\
\cline { 2 - 5 } & Step 1 & Step 2 & Step 3 & Step 4 \\
\hline $\mathbf{1 1 1}$ & 0.139 & - & - & - \\
$\mathbf{1 0 0}$ & $3.634^{*}$ & 2.081 & - & - \\
$\mathbf{0 1 0}$ & $3.561^{*}$ & $6.029^{* *}$ & $4.763^{* *}$ & $16.573^{* * *}$ \\
$\mathbf{0 0 1}$ & 0.002 & - & - & - \\
$\mathbf{1 1 0}$ & $0.147^{* *}$ & - & - & - \\
$\mathbf{1 0 1}$ & $4.357^{* *}$ & $12.511^{* * *}$ & 2.270 & - \\
$\mathbf{0 1 1}$ & $4.818^{* *}$ & 1.074 & - & - \\
\hline
\end{tabular}

* Significant at $10 \%$;* Significant at $5 \%$;**Significant at $1 \%$.

Table 7 shows the results of the complementarity tests undertaken. As we have previously verified (model I), the environmental impact of product innovation and process innovation is negative. It seems obvious that the implementation of both types of innovation seeks not to improve the environmental contribution of companies but to achieve greater economic efficiency. Now, with the complementarity tests, we try to determine whether the joint implementation of both types of innovation increases or decreases this negative environmental impact.

Table 7. The complementarity tests.

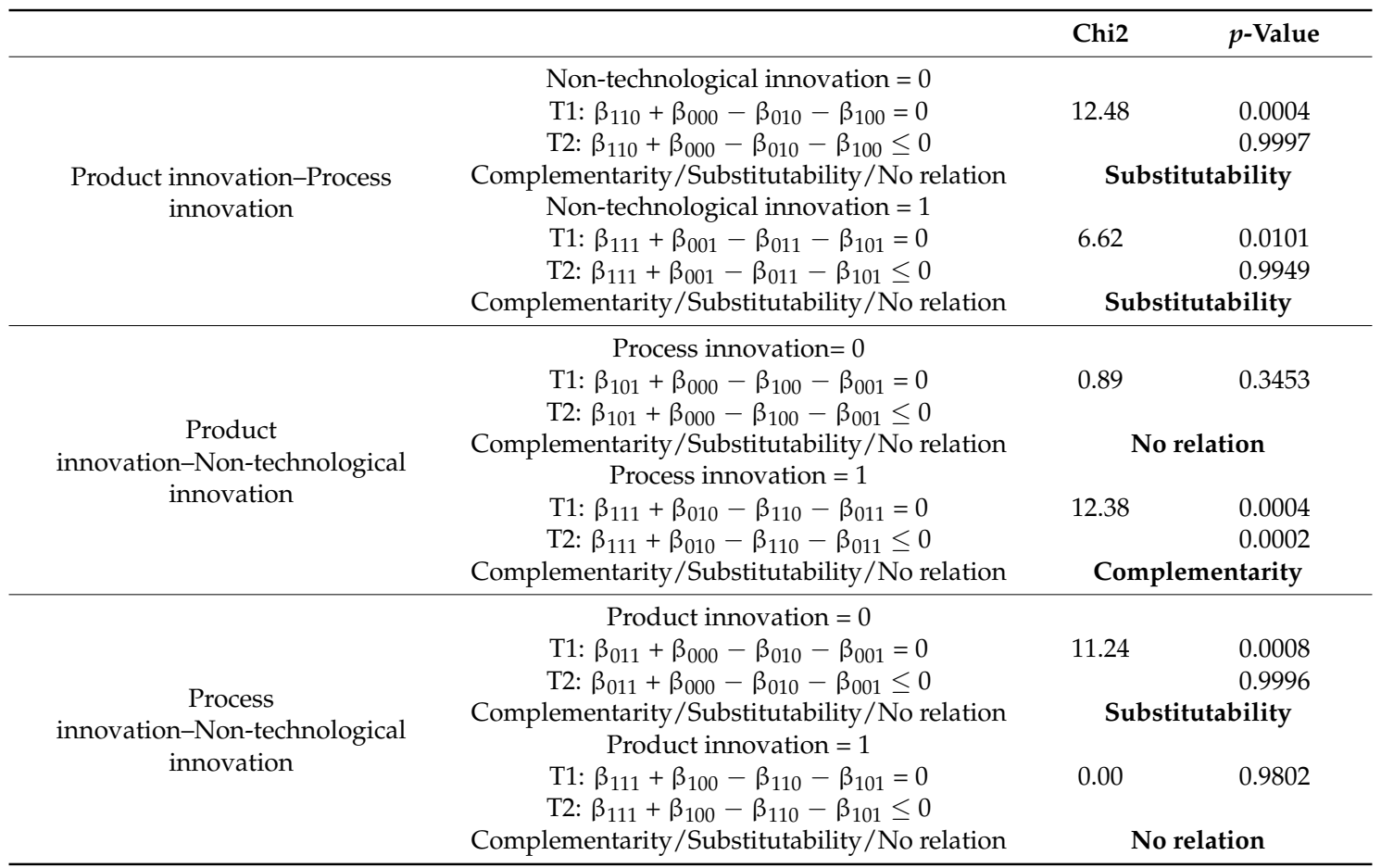

The complementarity test indicates that the relationship between product innovation and process innovation is substitutive. Therefore, this result supports Hypothesis 4. Consequently, the simultaneous implementation of both types of innovation further increases the negative environmental impact. It follows that with the current productive structure of the Spanish manufacturing industry — characterized by a small business size, financial difficulties, and a scarce presence of flexible technologies-the joint implementation of product innovation and process innovation is not environmentally appropriate. Consequently, everything seems to indicate that, with the current technological structure, Spanish manufacturing companies cannot simultaneously achieve the objectives of efficiency and the protection of the environment. However, when complementarity is 
analysed in relation to efficiency objectives (productivity, financial performance, etc.), the literature on innovation reports the existence of complementarity between product innovation and process innovation, both in the Spanish economy and in other economies (e.g., References [7,123]).

Due to its disruptive nature, product innovation is almost always accompanied by non-technological innovation since it is often necessary to modify or restructure the production process (process innovation and organizational innovation) and the implementation of new marketing practices (marketing innovation). If these are new products that seek to improve the environmental impact, these restructuring and new practices are even more necessary, so that we can expect a complementary relationship between the two types of innovation. In the environmental field, we do not know of studies that explicitly explore this relationship, and in the case of classical analyses of innovation, this type of study is very rare.

For example, Reference [7] finds that in Spain there is no relationship between product innovation and organizational innovation, while in France [6], this relationship is conditional complementary. In the strict environmental field, there are studies that postulate that 'sustainable innovations orientation will be greater in firms with higher levels of organizational slack than in firms with lower levels of organizational slack' [100]. Therefore, as long as there are possibilities to implement organizational innovations, sustainable innovation orientation will be greater, and with this, environmental performance will be greater. Obviously, this increases the likelihood of the existence of complementarity between organizational innovation and other types of innovation.

The relationship between product innovation and new marketing capabilities and its impact on firm performance is still less studied, although there are authors who stress that the success of the development and commercialization of new products is related to the implementation of marketing practices [124]. In this sense, there is a study that points out the existence of a correlation between marketing and R\&D capabilities and firm performance [125]. On the other hand, in the environmental field, evidence indicates that the relationship between environmental product innovation and marketing capabilities of a promotional nature has a positive impact on firm performance [14]. In general, marketing innovations are complements rather than substitutes for technological innovations [126].

In this study, the results of the hypothesis tests between product innovation and non-technological innovation partially support Hypothesis 5, since there is no relation among firms that do not perform process innovation, and the relation is complementary among firms that perform process innovation. Our finding has a certain similarity to References [6,7] for the relationship between product innovation and organizational innovation and to Reference [14] for the relationship between product innovation and marketing innovation. Finally, regarding the relationship between process innovation and non-technological innovation, the results of the complementarity tests support Hypothesis 6.

The role of marketing in companies that do not carry out product innovation is much smaller than that in companies that do engage in product innovation. Therefore, among companies that do not perform product innovation, the main weight of non-technological innovations (organizational and marketing) corresponds to organizational innovation. However, as we have already pointed out, process innovation and organizational innovation pursue the same objective of cost reduction. Thus, the relationship between these types of innovation can be substitutive. The results of the complementarity test in relation to Hypothesis 6 a are fully consistent with this intuition. In this regard, it should be noted that similar results are found by Reference [78] for Spanish service companies and by Reference [127] for Canadian manufacturing companies; they find, from the 2012 data, that organizational innovation reduced the number of process innovations by 2.3 per year. Reference [128] finds that introducing process innovation in isolation from product innovation does not induce the introduction of marketing innovation.

However, when the complementarity test between process innovation and non-technological innovation is carried out among companies that implement product innovation, the results indicate that there is no relationship between the two types of innovation, probably because the complementary 
natures of marketing and product innovation help to counteract the substitution effects between process innovation and organizational innovation. Therefore, the result of the complementarity test carried out also supports Hypothesis 6b. In this sense, numerous studies indicate the existence of evidence of complementarity between product innovation and marketing innovation (e.g., References $[126,128,129])$.

\section{Conclusions}

This study analyses the contribution of product innovation, process innovation, and non-technological innovation (organizational and marketing) to the achievement of a lower environmental impact (environmental performance). It does so from two different but related perspectives. First, it analyses the individual contribution of the three types of innovation simultaneously. In the environmental field, most studies tend to focus on the analysis of a single type of innovation (e.g., References [14,37]). Second, it explores the existence of positive synergies (complementarities) or negative synergies (substitutabilities) in the six pairs of possible combinations between the three types of innovation considered. This analysis allows us to determine which combinations of innovation types increase/decrease environmental performance. Therefore, it sheds light on the cocktails of types of innovation that result in a better/worse environmental performance, constituting an important guide for the decision making of managers and political decision makers. As far as our knowledge reaches, this type of analysis has not yet been carried out in the environmental field.

In relation to the first perspective, the empirical analysis shows that product innovation has a negative influence on environmental performance, although this influence is not statistically significant. Likewise, it indicates that process innovation has a negative and statistically significant influence on environmental performance. This result is similar to that obtained by Reference [130] who found that technology orientation has a non-significant effect and a negative effect on different measures of environmental performance.

Both results indicate that, in the Spanish manufacturing sector, the performance of product and process innovation is not at the service of a reduction of the corresponding environmental impacts. We intuit that these two innovations are preferably used to try to improve the economic efficiency of companies and, therefore, their survival. In this sense, it must be borne in mind that, on average, Spanish manufacturing companies are significantly smaller than their European counterparts, invest less in R\&D, and achieve lower levels of productivity. In these circumstances, their level of financial precariousness is very high, so they devote most of their energy to the struggle for survival. Consequently, for these companies, the environmental culture plays a secondary role. This poor environmental performance is aggravated by the technological structure (traditional technology versus flexible technology) exhibited by Spanish manufacturing companies, with a predominant use of traditional technologies. Traditional technologies are single lane, so the companies that use them face extreme difficulties in reaching different objectives simultaneously, especially if the pursuit of these objectives has contradictory impacts. For example, in the literature on environmental innovation, it is often argued that there is a conflict between environmental protection and firm performance since environmental improvement efforts increase the costs of companies and erode their bases of profitability [131,132]. However, flexible technologies allow for the efficient pursuit of different objectives simultaneously, facilitating the achievement of a reasonable reconciliation between economic efficiency and environmental protection.

On the other hand, the empirical analysis shows that non-technological innovation has an important influence, which is positive and statistically significant, on environmental performance. This result also coincides with other previous investigations. Thus, some authors have found that organizational innovation [133] and a strong market orientation [130] have an important and positive influence on environmental performance. Additionally, this result is a clear indication that Spanish manufacturing companies use technological innovation to achieve efficiency and non-technological 
innovation for the simultaneous achievement of efficiency and improved environmental protection. This is because non-technological innovation exhibits a high degree of flexibility, which allows different objectives to be met simultaneously.

In relation to the findings of the different combinations of the different types of innovation, we find that the relationship between product innovation and process innovation is unconditionally substitutive to the extent that there is complementarity between companies that do not implement non-technological innovation and among those that do implement it. This result reinforces the position of those researchers who have pointed out that the association between a greater technology orientation and a better firm environmental performance is probably too simplistic [130,134]. Therefore, with the current technological structure of Spanish manufacturing companies, the joint implementation of both types of innovation is not recommended from the perspective of environmental protection. However, from the perspective of economic efficiency, the interaction between the two types of innovation is complementary [7], so their joint implementation is recommended. Again, the use of traditional technologies poses a crucial dilemma for Spanish manufacturing companies: efficiency or protection of the environment.

On the other hand, the empirical results indicate that the relationship between product innovation and non-technological innovation is conditionally complementary since, among companies that do not implement process innovation, there is no relationship between the two types of innovation and, among those that implement process innovation, this relationship is complementary. Therefore, once again, we find that non-technological innovation has enormous potential to contribute to the improvement of the environment. In this case, the protagonist role of non-technological innovation probably corresponds to marketing capabilities, since new green products need to develop a powerful orientation towards the market. Therefore, from the perspective of protecting the environment, the simultaneous implementation of product innovation and non-technological innovation is recommended.

Finally, we verify that the relationship between process innovation and non-technological innovation is conditionally substitutive insofar as there is substitutability only between companies that do not implement product innovation. Therefore, in this type of company, the simultaneous implementation of process innovation and non-technological innovation is not convenient since environmental performance decreases. However, among the companies that perform product innovation, the complementarity test indicates that there is no relationship between process innovation and non-technological innovation; that is, in this case, the relationship between the two types of innovation does not improve or worsen the environmental performance.

Of all the findings, it is inferred that, with the current technological structure of Spanish manufacturing companies, non-technological innovation plays a leading role in protecting the environment.

These findings have important implications for both managers and political decision makers. With the current technological structure and the growing pressure from stakeholders to improve environmental protection, managers must take into account that non-technological innovation is an important instrument that contributes to achieving both economic objectives and those related to environmental protection simultaneously. Obviously, if their ambition is not only to survive but to achieve leadership, both in economic and in environmental terms, they should probably incorporate flexible technologies that help them to improve the efficiency of their production processes and contribute to the improvement of the environment.

Political decision makers influence companies' allocation of resources through their laws and regulations. In this sense, they design policies to promote innovation with the aim of ensuring that efficient, competitive, and environmentally friendly companies exist in their country. Based on the findings of this study, it is clear that the public policies to support innovation must have a special predilection for investments that incorporate non-technological innovation, both organizationally and marketing, since this kind of innovation has a direct and positive influence on the environmental 
performance. Likewise, it also shows an indirect and positive influence on environmental performance, as a consequence of its complementarity with product innovation.

We recognize that our paper is not without its limitations, some of which are opportunities for new studies. Our empirical study uses PITEC data. The use of public databases has the disadvantage that their questionnaires have not been designed specifically for our research, so in some cases, we are forced to create proxy variables, since some variables that interest us are not present in the polls. This happens with our variable environmental performance.

To implement the complementarity approach, it is necessary to use a performance measure. In this study, we use environmental performance. However, using CIS survey data limits the scope and sensitivity of the environmental performance variable, since the PITEC is not specifically designed to create the environmental performance variable. In addition, the Spanish CIS survey data do not provide direct information on product environmental innovation, process environmental innovation, organizational environmental innovation, and marketing environmental innovation. The Spanish CIS survey data do not differentiate between environmental innovation and non-environmental innovation. Therefore, on the basis of ad hoc surveys and the complementarity approach, it would be desirable for future research to use other measures of environmental performance and environmental innovations. These new studies will allow us to verify whether the results obtained in our study are maintained.

In addition to those indicated, other limitations can lead to further research directions. First, as this study is focused on the entire Spanish manufacturing sector, where the presence of traditional technologies is the majority, future studies should consider samples from companies with different technological intensities in order to check if the majority presence of flexible technologies leads to different results. Second, our findings are not only applicable to the Spanish economy, but probably also to the economy of those countries that have a similar technological structure. Therefore, other national contexts should be analyzed in order to verify that it is the singularity of the technological structure, and not the national context, that determines the sign and the significance of the variables analyzed. Finally, future studies should consider longitudinal data. This type of data allows us to obtain robust estimators, facilitating the overcoming of the problems caused by the unobservable heterogeneity present mainly in the cross-section data [135].

Author Contributions: M.G.-G. and J.G.-B. designed the research, analyzed the data and interpreted the results. J.G.-B. drew up the theoretical framework. J.L.C.-P. provided extensive suggestion throughout the study regarding the Introduction, Methodology, Results and Discussion, and revised the manuscript. M.G.-G. contributed to refining the theoretical arguments. All authors discussed the research, cooperated with each other to revise the paper, and have read and approved the final manuscript.

Acknowledgments: The presentation of this work has been possible thanks to the funding granted by the European Regional Development Fund of the European Union and Junta de Extremadura to the research group DELSOS (Grant no. GR18095).

Conflicts of Interest: The authors declare no conflicts of interest.

\section{References}

1. Van Leeuwen, G.; Mohnen, P.A. Revisiting the Porter hypothesis: An empirical analysis of green innovation for the Netherlands. Econ. Innov. New Technol. 2017, 26, 63-77. [CrossRef]

2. Kemp, R.; Pearson, P. Final Report MEI Project about Measuring Ecoinnovation; UM Merit: Maastricht, The Netherlands, 2007.

3. Klewitz, J.; Hansen, E.G. Sustainability-oriented innovation of SMEs: A systematic review. J. Clean. Prod. 2014, 65, 57-75. [CrossRef]

4. OECD \& Eurostat. Oslo Manual_Proposed Guidelines for Collecting and Interpreting Technological Innovation Data; OECD \& Eurostat: Paris, France, 2005.

5. Galia, F.; Ingham, M.; Pekovic, S. Environmental benefits of forms of innovations in French manufacturing firms. In Proceedings of the XXII Conférence Internationale de Management Stratégique, Clermont-Ferrand, France, 9-12 June 2013. 
6. Ballot, G.; Fakhfakh, F.; Galia, F.; Salter, A. The fateful triangle. Complementarities between product, process and organizational innovation in the UK and France. Res. Policy 2015, 44, 217-232. [CrossRef]

7. Guisado-González, M.; Wright, L.T.; Guisado-Tato, M. Product-process matrix and complementarity approach. J. Technol. Transf. 2017, 42, 441-459. [CrossRef]

8. Mairesse, J.; Robin, S. The importance of process and product innovation for French manufacturing and service industries. In Innovation and Growth, from RED Strategies of Innovation Firms to Economy-Wide Technological Change; Andersson, M., Johansson, B., Karlsson, C., Lööf, H., Eds.; Oxford University Press: Great Britain, UK, 2012; pp. 128-159.

9. Topkis, D.L. Minimizing a submodular function on a lattice. Oper. Res. 1978, 26, 305-321. [CrossRef]

10. Milgrom, P.; Roberts, J. The economics of modern manufacturing: Technology, strategy, and organization. Am. Econ. Rev. 1990, 80, 511-528.

11. Guisado-González, M.; González-Blanco, J.; Coca-Pérez, J.L. Analyzing the relationship between exploration, exploitation and organizational innovation. J. Knowl. Manag. 2017, 21, 1142-1162. [CrossRef]

12. Mohnen, P.; Röller, L.H. Complementarities in innovation policy. Eur. Econ. Rev. 2005, 49, 1431-1450. [CrossRef]

13. Rothwell, R. Industrial innovation: Success, strategy, trends. In The Handbook of Industrial Innovation; Dodgson, M., Rothwell, R., Eds.; Edward Elgar: Cheltenham, UK, 1994.

14. Amores-Salvadó, J.; Castro, M.; Navas-lópez, J. Green corporate image: Moderating the connection between environmental product innovation and firm performance. J. Clean. Prod. 2014, 83, 356-365. [CrossRef]

15. Konar, S.; Cohen, M. Does the market value environmental performance? Rev. Econ. Stat. 2001, 83, $281-289$. [CrossRef]

16. Rexhäuser, S.; Rammer, C. Environmental innovations and firm profitability: Unmasking the Porter hypothesis. Environ. Resour. Econ. 2014, 57, 145-167. [CrossRef]

17. Dangelico, R.M.; Pontrandolfo, P. Being "green and competitive": The impact of environmental actions and collaborations on firm performance. Bus. Strat. Environ. 2015, 24, 413-443. [CrossRef]

18. Mazzi, A.; Toniolo, S.; Manzardo, A.; Ren, J.; Scipioni, A. Exploring the direction on the environmental and business performance relationship at the firm level. Lessons from a literature review. Sustainability 2016, 8, 1200. [CrossRef]

19. Porter, M.E. America's green strategy. Sci. Am. 1991, 264, 168. [CrossRef]

20. Porter, M.E.; van der Linde, C. Toward a new concept of the environment-competitiveness relationship. J. Econ. Perspect. 1995, 9, 97-118. [CrossRef]

21. Hart, S.L.; Ahuja, G. Does it pay to be green? An empirical examination of the relationship between emission reduction and firm performance. Bus. Strategy Environ. 1996, 5, 30-37. [CrossRef]

22. Boons, F. Greening products: A framework for product chain management. J. Clean. Prod. 2002, 10, 495-505. [CrossRef]

23. Wagner, M. Innovation and competitive advantages from the integration of strategic aspects with social and environmental management in European firms. Bus. Strategy Environ. 2008, 18, 291-306. [CrossRef]

24. Chen, Y. The driver of green innovation and green image: Green core competence. J. Bus. Ethics 2008, 81, 531-543. [CrossRef]

25. Christmann, P. Effects of "best practices" of environmental management on cost advantage: The role of complementary assets. Acad. Manag. J. 2000, 43, 663-680.

26. OECD. Sustainable Manufacturing and Eco-Innovation. Framework, Practices and Measurement; OECD: Paris, France, 2009.

27. Rashid, L.; Yahya, S.; Shamee, S.A.; Jabar, J.; Sedek, M.; Halim, S. Eco product innovation in search of meaning: Incremental and radical practice for sustainability development. Asian Soc. Sci. 2014, 10, 78-88. [CrossRef]

28. Cleff, T.; Rennings, K. Determinants of environmental product and process innovation. Eur. Environ. 1999, 9, 191-201. [CrossRef]

29. Pujari, D. Eco-innovation and new product development: Understanding the influences on market performance. Technovation 2006, 26, 76-85. [CrossRef]

30. Fiksel, J. Design for the Environment: Creating Eco-Efficient Products and Processes; McGraw-Hill: New York, NY, USA, 2001. 
31. Dangelico, R.M.; Pujari, D. Mainstreaming green product innovation: Why and how companies integrate environmental sustainability. J. Bus. Ethics 2010, 95, 471-486. [CrossRef]

32. Yu, W.; Ramanathan, R. An empirical examination of stakeholder pressures, green operations practices and environmental performance. Int. J. Prod. Res. 2015, 53, 6390-6407. [CrossRef]

33. Shrivastava, P. Environmental technologies and competitive advantage. Strat. Manag. J. 1995, 16, $183-200$. [CrossRef]

34. Marchi, V. Environmental innovation and R\&D cooperation: Empirical evidence from Spanish manufacturing firms. Res. Policy 2012, 41, 614-623.

35. Hervas-Oliver, J.L.; Sempere-Ripoll, F.; Rojas Alvarado, R.; Estelles-Miguel, S. Beyond product innovation: Deciphering process-oriented innovators, complementarities and performance effects. Technol. Anal. Strat. 2018, 30, 582-595. [CrossRef]

36. Dangelico, R.M.; Pujari, D.; Pontrandolfo, P. Green product innovation in manufacturing firms: A sustainability-oriented dynamic capability perspective. Bus. Strat. Environ. 2017, 26, 490-506. [CrossRef]

37. Moyano-Fuentes, J.; Maqueira-Marín, J.M.; Bruque-Cámara, S. Process innovation and environmental sustainability engagement: An application on technological firms. J. Clean. Prod. 2018, 171, 844-856. [CrossRef]

38. Wang, L.; Madhok, A.; Li, S.X. Agglomeration and clustering over industry life cycle: Toward a dynamic model of geographic concentration. Strat. Manag. J. 2014, 35, 995-1012. [CrossRef]

39. Costa-Campi, M.T.; García-Quevedo, J.; Segarra, A. Energy efficiency determinants: An empirical analysis of Spanish innovative firms. Energy Policy 2015, 83, 229-239. [CrossRef]

40. Tsai, K.-H.; Liao, Y.-C. Innovation capacity and the implementation of eco-innovation: Toward a contingency perspective. Bus. Strat. Environ. 2017, 26, 1000-1013. [CrossRef]

41. Nidumou, R.; Prahalad, C.K.; Rangaswami, M.R. Why sustainability is now the key driver of innovation. Harv. Bus. Rev. 2009, 87, 56-64.

42. Wagner, M. How to reconcile environmental and economic performance to improve corporate sustainability: Corporate environmental strategies in the European paper industry. J. Environ. Manag. 2005, 76, 105-118. [CrossRef] [PubMed]

43. Yamakawa, Y.; Haibin Yang, H.; Linc, Z. Exploration versus exploitation in alliance portfolio: Performance implications of organizational, strategic, and environmental fit. Res. Policy 2011, 40, 287-296. [CrossRef]

44. Sutton, J. Gibrat's legacy. J. Econ. Lit. 1997, 35, 40-59.

45. Sørensen, J.B.; Stuart, T.E. Aging, obsolescence, and organizational innovation. Admin. Sci. Quart. 2000, 45, 81-112. [CrossRef]

46. Agarwal, R.; Sarkar, M.B.; Echambadi, R. The conditioning effect of time on firm survival: An industry life-cycle approach. Acad. Manag. J. 2002, 45, 971-994.

47. Roxburgh, C.; Labaye, E.; Thompson, F.; Tacke, T.; Kauffman, D. Investing in Growth: Europe's Next Challenge. McKinsey Global Institute, 2012. Available online: https://www.mckinsey.com/ / media/McKinsey/Featured\%20Insights/Europe/Investing\%20in\%20growth/MGI_Europe_Investing_ Executive_Summary_Dec2012.ashx (accessed on 16 July 2018).

48. Arroyo-Gutiérrez, L.M.; Jiménez-Partearroyo, M. Mass customization within the company's competitive framework. Dirección y Organización 2013, 49, 44-53.

49. Horbach, J. Determinants of environmental innovation-New evidence from German panel data sources. Res. Policy 2008, 37, 163-173. [CrossRef]

50. Kesidou, E.; Demirel, P. On the drivers of eco-innovations: Empirical evidence from the UK. Res. Policy 2012, 41, 862-870. [CrossRef]

51. Albort-Morant, G.; Leal-Millán, A.; Cepeda-Carrion, G.; Henseler, J. Developing green innovation performance by fostering of organizational knowledge and coopetitive relations. Rev. Manag. Sci. 2018, 12, 499-517. [CrossRef]

52. Aragon-Correa, J.; Sharma, S. A contingent resource-based view of proactive corporate environmental strategy. Acad. Manag. Rev. 2003, 28, 71-89. [CrossRef]

53. Bowen, F.E.; Cousins, P.D.; Lamming, R.C.; Faruk, A.C. The role of supply management capabilities in green supply. Prod. Oper. Manag. 2001, 10, 174-190. [CrossRef]

54. Ma, Y.; Hou, G.; Xin, B. Green process innovation and innovation benefit: The mediating effect of firm image. Sustainability 2017, 9, 1778 . 
55. Song, M.; Benedetto, A.D.; Nason, R.W. Capabilities and financial performance: The moderating effect of strategic type. J. Acad. Mark. Sci. 2007, 35, 18-34. [CrossRef]

56. Nath, P.; Nacchiapan, S.; Ramanathan, R. The impact of marketing capability, operations capability and diversification strategy on performance: A resource-based view. Ind. Mark. Manag. 2010, 39, 307-329. [CrossRef]

57. Ahmed, M.U.; Kristal, M.M.; Pagell, M. Impact of operational and marketing capabilities on firm performance: Evidence from economic growth and downturns. Int. J. Prod. Econ. 2014, 154, 59-71. [CrossRef]

58. Yu, W.; Ramanathan, R.; Nath, P. The impacts of marketing and operations capabilities on financial performance in the UK retail sector: A resource-based perspective. Ind. Mark. Manag. 2014, 43, 25-31. [CrossRef]

59. Yu, W.; Ramanathan, R. Environmental management practices and environmental performance: The roles of operations and marketing capabilities. Ind. Manag. Data Syst. 2016, 116, 1201-1222. [CrossRef]

60. Yu, W.; Ramanathan, R.; Nath, P. Environmental pressures and performance: An analysis of the roles of environmental innovation strategy and marketing capability. Technol. Forecast. Soc. 2017, 117, 160-169. [CrossRef]

61. Hayes, R.H.; Wheelwright, S.C. Link manufacturing process and product life cycles. Harv. Bus. Rev. 1979, 57, 133-140.

62. Hayes, R.H.; Wheelwright, S.C. The dynamics of process-product life cycles. Harv. Bus. Rev. 1979, 57, 127-136.

63. Abernathy, W.J.; Townsend, P.L. Technology, productivity, and process change. Technol. Forecast. Soc. Chang. 1975, 7, 379-396. [CrossRef]

64. Utterback, J.; Abernathy, W.J. A dynamic model of process and product innovation. Omega Int. J. Manag. Sci. 1975, 3, 639-656. [CrossRef]

65. Safizadeh, M.H.; Ritzman, L.P.; Sharma, D.; Wood, C. An empirical analysis of the product-process matrix. Manag. Sci. 1996, 42, 1576-1591. [CrossRef]

66. McDermott, C.M.; Greis, N.P.; Fischer, W.A. The diminishing utility of the product/process matrix-A study of the US power tool industry. Int. J. Oper. Prod. Manag. 1997, 17, 65-84. [CrossRef]

67. Ahmad, S.; Schroeder, R.G. Refining the product-process matrix. Int. J. Oper. Prod. Manag. 2002, $22,103-124$. [CrossRef]

68. Castro, E.; Fernández, I. La I+D empresarial y sus relaciones con la investigación pública española. In Radiografía de la Investigación Pública en España; Sebastián, J., Muñoz, E., Eds.; Biblioteca Nueva: Madrid, Spain, 2006.

69. Hollanders, H.; Es-Sadki, N. Innovation Union Scoreboard 2013; Maastricht Economic and Social Research Institute on Innovation and Technology, UNU-MERIT: Maastricht, The Netherlands, 2013.

70. Danneels, E. The dynamics of product innovation and firm competencies. Strat. Manag. J. 2002, 23, $1095-1121$. [CrossRef]

71. Bharadwaj, S.; Menon, A. Making innovation happen in organizations: Individual creativity mechanisms, organizational creativity mechanisms or both? J. Prod. Innov. Manag. 2000, 17, 424-434. [CrossRef]

72. Walker, R.M. Innovation and organizational performance: A critical review of the evidence and a research agenda. Acad. Manag. Annu. Meet. Proc. 2005, 8, 1-6. [CrossRef]

73. Leiponen, A.; Helfat, C.E. Innovation objectives, knowledge sources, and the benefits of breadth. Strat. Manag. J. 2010, 31, 224-236. [CrossRef]

74. Schmidt, T.; Rammer, C. Non-technological and technological Innovation: Strage Bedfellows? In ZEW Discussion Paper 07-052; Centre for European Economic Research: Mannheim, Germany, 2007.

75. Hervas-Oliver, J.L.; Sempere-Ripoll, F.; Boronat-Moll, C. Process innovation strategy in SMEs, organizational innovation and performance: A misleading debate? Small. Bus. Econ. 2014, 43, 873-886. [CrossRef]

76. Germain, R. The role of context and structure in radical and incremental logistics innovation adoption. J. Bus. Res. 1996, 35, 117-127. [CrossRef]

77. Moorman, C.; Slotegraaf, R.J. The contingency value of complementary capabilities in product development. J. Mark. Res. 1999, 36, 239-257. [CrossRef]

78. González-Blanco, J.; Coca-Pérez, J.L.; Guisado-González, M. Relations between technological and non-technological innovations in the service sector. Serv. Ind. J. 2018. [CrossRef] 
79. Baranano, A.M. The non-technological side of technological innovation: State-of-the-art and guidelines for further empirical research. Int. J. Entrep. Innov. Manag. 2003, 3, 107-125. [CrossRef]

80. Freeman, C. The national system of innovation in historical perspective. Cambridge. J. Econ. 1995, 19, 5-24.

81. Drejer, A. Situations for innovation management: Towards a contingency model. Eur. J. Innov. Manag. 2002, 55, 4-17. [CrossRef]

82. Mothe, C.; Nguyen-Thi, T.U. Non-technological and technological innovations: Do services differ from manufacturing? An empirical analysis of Luxembourg firms. Int. J. Technol. Manag. 2012, 57, 227-244. [CrossRef]

83. O'Sullivan, D.; Dooley, L. Applying Innovation; Sage Publications: London, UK, 2009.

84. Yang, H.L.; Hsiao, S.L. Mechanisms of developing innovative IT-Enabled services: A case study of Taiwanese healthcare service. Technovation 2009, 29, 327-337. [CrossRef]

85. Meroño-Cerdán, A.L.; López-Nicolás, C. Innovation objectives as determinants of organizational innovations. Innovation 2017, 19, 208-226. [CrossRef]

86. Huerta Arribas, E.; García Olaverri, C.; Garcés Galdeano, L. El tamaño de las empresas y la calidad del recurso empresarial: ¿causa o efecto? Ekonomiaz 2016, 90, 32-55.

87. Shin, M. A framework for evaluating economics of knowledge management systems. Inf. Manag. 2004, 42, 179-196. [CrossRef]

88. Griffin, A.; Hauser, J.R. Integrating R\&D and marketing: A review and analysis of the literature. J. Prod. Innov. Manag. 2001, 13, 191-215.

89. Tinoco, J.K. Marketing innovation: The unheralded innovation vehicle to sustained competitive advantage. Int. J. Sustain. Strateg. Manag. 2010, 2, 168-183. [CrossRef]

90. De Luca, L.M.; Atuahene-Gima, K. Market knowledge dimensions and cross-functional collaboration: Examining the different routes to product innovation performance. J. Mark. 2007, 71, 95-112. [CrossRef]

91. Ardito, L.; Besson, E.; Messeni Petruzzelli, A.; Gregori, G.L. The influence of production, IT, and logistics process innovations on ambidexterity performance. Bus Process. Manag. J. 2018, 24, 1271-1284. [CrossRef]

92. Ghisettia, C.; Marzucchi, A.; Montresor, S. The open eco-innovation mode. An empirical investigation of eleven European countries. Res. Policy 2015, 44, 1080-1093. [CrossRef]

93. Cainelli, G.; De Marchi, V.; Grandinetti, R. Does the development of environmental innovation require different resources? Evidence from Spanish manufacturing firms. J. Clean. Prod. 2015, 94, 211-220. [CrossRef]

94. del Río, P.; Peñasco, C.; Romero-Jordán, D. Distinctive Features of Environmental Innovators: An Econometric Analysis. Bus. Strat. Environ. 2015, 24, 361-385. [CrossRef]

95. Horbach, J. Empirical determinants of eco-innovation in European countries using the community innovation survey. Environ. Innov. Soc. Transit. 2016, 19, 1-14. [CrossRef]

96. Arundel, A.; Smith, K. History of the community innovation survey. In Handbook of Innovation Indicators and Measurement; Gault, F., Ed.; Edward Elgar Publishing Limited: Cheltenham, UK, 2013; pp. 60-70.

97. Mairesse, J.; Mohnen, P. The importance of R\&D for innovation: A reassessment using French survey data. J. Technol. Transf. 2005, 30, 183-197.

98. Alquézar Sabadie, J.; Kwiatkowski, C. The Community Innovation Survey and the Innovation Performance of Enterprises Funded by EU's Framework Programmes; European Commission-DG Research and Innovation: Brussels, Belgium, 2016.

99. Kunapatarawonga, R.; Martínez-Ros, E. Towards green growth: How does green innovation affect employment? Res. Policy 2016, 45, 1218-1232. [CrossRef]

100. Varadarajan, R. Innovating for sustainability: A framework for sustainable innovations and a model of sustainable innovations orientation. J. Acad. Mark. Sci. 2017, 45, 14-36. [CrossRef]

101. Chesbrough, H. Open Innovation. The New Imperative for Creating and Profiting from Technology; Harvard Business School Press: Harvard, MA, USA, 2003.

102. Suárez-Porto, V.; Guisado-González, M. Analysis of the determinants of exporting intensity in the field of innovation. Investigaciones Europeas de Dirección y Economía de la Empresa 2014, 20, 79-86. [CrossRef]

103. Chiarvesio, M.; De Marchi, V.; Di Maria, E. Environmental innovations and internationalization: Theory and practices. Bus. Strat. Environ. 2015, 24, 790-801. [CrossRef]

104. Cui, J.; Lapan, H.; Moschini, G. Productivity, export, and environmental performance: Air pollutants in the United States. Am. J. Agric. Econ. 2016, 98, 447-467. [CrossRef] 
105. Choo, K.; Lee, K.; Ryu, K.; Yoon, J. Changing performance of business groups over two decades: Technological capabilities and investment efficiency in Korean Chaebols. Econ. Dev. Cult. Chang. 2009, 57, 359-386. [CrossRef]

106. Piga, C.; Vivarelli, M. Internal and external R\&D: A sample selection approach. Oxf. Bull. Econ. Stat. 2004, $66,457-482$.

107. Cohen, W.M. Fifty years of empirical studies of innovative activity and performance. In Handbook of the Economics of Innovation; Hall, B.H., Rosenberg, N., Eds.; Elsevier Science: Amsterdam, The Netherlands, 2010; pp. 129-213.

108. Pereira, A.; Vence, X. Key business factors for eco-innovation: An overview of recent firm-level empirical studies. Cuadernos de Gestión 2012, 12, 73-103. [CrossRef]

109. Schumpeter, J.A. Theory of Economic Development: An Enquiry into Profits, Capital, Interest and the Business Cycle; Harvard University Press: Cambridge, MA, USA, 1934.

110. Cainelli, G.; Evangelista, R.; Savona, M. Innovation and economic performance in services: A firm-level analysis. Camb. J. Econ. 2006, 30, 435-458. [CrossRef]

111. Löschel, A. Technological change in economic models of environmental policy: A survey. Ecol. Econ. 2002, 43, 105-126. [CrossRef]

112. Grubb, M.; Edmonds, J.; ten Brink, P.; Morrison, M. The costs of limiting fossil-fuel $\mathrm{CO}_{2}$ emissions: A survey and analysis. Annu. Rev. Energy Environ. 1993, 18, 397-478. [CrossRef]

113. van Beveren, I.; Vandenbussche, H. Product and process innovation and firms' decision to export. J. Econ. Policy Reform 2010, 13, 3-24. [CrossRef]

114. Ganotakis, P.; Love, J.H. R\&D, product innovation, and exporting: Evidence from UK new technology based firms. Oxf. Econ. Pap. 2011, 63, 279-306.

115. Ennen, E.; Richter, A. The whole is more the sum of its parts-Or is it? A review of the empirical literature on complementarities in organizations. J. Manag. 2010, 36, 207-233. [CrossRef]

116. Belderbos, R.; Carree, M.; Lokshin, B. Complementarity in R\&D cooperation strategies. Rev. Ind. Organ. 2006, 28, 401-426.

117. González-Benito, J.; González-Benito, O. A study of the motivations for the environmental transformation of Companies. Ind. Mark. Manag. 2005, 34, 462-475. [CrossRef]

118. Smirnova, M.; Henneberg, S.C.; Ashnai, B.; Naudé, P.; Mouzas, S. Understanding the role of marketing-purchasing collaboration in industrial markets: The case of Russia. Ind. Mark. Manag. 2011, 40, 54-64. [CrossRef]

119. Wagner, M. On the relationship between environmental management, environmental innovation and patenting: Evidence from German manufacturing firms. Res. Policy 2007, 36, 1587-1602. [CrossRef]

120. Prajogo, D.I.; Sohal, A.S. The relationship between TQM practices, quality performance, and innovation performance: An empirical examination. Int. J. Qual. Reliab. Manag. 2003, 20, 901-918. [CrossRef]

121. Zhu, Q.; Sarkis, J.; Lai, K.H. Green supply chain management innovation diffusion and its relationship to organizational improvement: An ecological modernization perspective. J. Eng. Technol. Manag. 2012, 29, 168-185. [CrossRef]

122. Tabesh, A.R.; Batt, P.J.; Butler, B. Modelling the impact of environmental and organizational determinants on green supply chain innovation and performance. J. Food Prod. Mark. 2016, 22, 436-454. [CrossRef]

123. Mantovani, A. Complementarity between product and process innovation in a monopoly setting. Econ. Innov. New Technol. 2006, 15, 219-234. [CrossRef]

124. Gupta, A.K.; Raj, S.P.; Wilemon, D. A Model for Studying R\&D-Marketing interface in the product innovation process. J. Mark. 1986, 50, 7-17.

125. Dutta, S.; Narasimhan, O.; Rajiv, S. Success in High-Technology Markets: Is Marketing Capability Critical? Mark. Sci. 1999, 18, 547-568. [CrossRef]

126. Schubert, T. Marketing and organisational innovations in entrepreneurial innovation processes and their relation to market structure and firm characteristics. Rev. Ind. Organ. 2010, 36, 189-212. [CrossRef]

127. Cozzarin, B.P. Impact of organizational innovation on product and process innovation. Econ. Innov. New Technol. 2017, 26, 405-417. [CrossRef]

128. Kijek, T. An empirical analysis of the relationship between technological and marketing innovations: A case of polish manufacturing firms. Oeconomia 2013, 12, 15-25. 
129. Lewis, M.J.; Wackowski, O. Dealing with an innovative industry: A look at flavored cigarettes promoted by mainstream brands. Am. J. Public Health 2006, 96, 244-251. [CrossRef] [PubMed]

130. Ardito, L.; Dangelico, R.M. Firm environmental performance under scrutiny: The role of strategic and organizational orientations. Corp. Soc. Responsib. Environ. Mgmt. 2018, 25, 426-440. [CrossRef]

131. Eiadat, Y.; Kelly, A.; Roche, F.; Eyadat, H. Green and competitive? An empirical test of the mediating role of environmental innovation strategy. J. World Bus. 2008, 43, 131-145. [CrossRef]

132. Stefan, A.; Paul, L. Does it pay to be green? A systematic overview. Acad. Manag. Perspect. 2008, $22,45-62$. [CrossRef]

133. Mirghafoori, S.H.; Andalib, D.; Keshavarz, P. Developing green performance through supply chain agility in manufacturing industry: A case study approach. Corp. Soc. Responsib. Environ. Manag. 2017, 24, 368-381. [CrossRef]

134. Oltra, V.; Saint Jean, M. Sectoral systems of environmental innovation: An application to the French automotive industry. Technol. Forecast. Soc. 2009, 76, 567-583. [CrossRef]

135. Miravete, E.; Pernias, J. Innovation complementarity and scale of production. J. Ind. Econ. 2006, 54, 1-29. [CrossRef]

(C) 2018 by the authors. Licensee MDPI, Basel, Switzerland. This article is an open access article distributed under the terms and conditions of the Creative Commons Attribution (CC BY) license (http://creativecommons.org/licenses/by/4.0/). 